\title{
Bioethanol Production from Rice Straw Enzymatically Saccharified by Fungal Isolates, Trichoderma viride F94 and Aspergillus terreus F98
}

\author{
Mervate A. Abo-State1, Ahmed M. E. Ragab², Nour Sh. EL-Gendy33, Laila A. Farahat ${ }^{3}$, \\ Hekmat R. Madian ${ }^{3}$ \\ ${ }^{1}$ National Center for Radiation Research and Technology (NCRRT), Cairo, Egypt \\ ${ }^{2}$ Faculty of Science (Girls Branch), Al-Azhar University, Cairo, Egypt \\ ${ }^{3}$ Egyptian Petroleum Research Institute (EPRI), Cairo, Egypt \\ Email: ${ }^{*}$ hekmat 7777@yahoo.com
}

Received 17 April 2014; revised 5 May 2014; accepted 13 June 2014

Copyright (C) 2014 by authors and Scientific Research Publishing Inc.

This work is licensed under the Creative Commons Attribution International License (CC BY). http://creativecommons.org/licenses/by/4.0/ c) (i) Open Access

\section{Abstract}

Egypt faces a high population growth rate nowadays, which demands for an increase in agricultural production efficiency. Consequently, agricultural field residues will increase. Rice straw is one of the main agriculture residues in Egypt. So this study was performed on rice straw as a resource for production of bioethanol. Eight microbial isolates, five yeasts and three fungi were isolated from rice straw. Yeast isolates were selected for their ability to utilize different sugars and cellulose. Chipped and grinded rice straw was subjected to different pretreatment methods physically through steam treatment by autoclaving and different doses of gamma $\gamma$ irradiation (50 and 70 Mrad). Autoclaved pretreated rice straw was further enzymatically treated throughout solid state fermentation process by different fungal isolates; F68, F94 and F98 producing maximum total reducing sugars of 12.62, 13.58, 17.00 g/L, respectively. Bioethanol production by separate microbial hydrolysis and fermentation (SHF) process of rice straw hydrolysate was performed by the two selected fungal isolates; Trichoderma viride F94 and Aspergillus terreus F98 and two yeast isolates (Y26 and Y39). The two yeast isolates have been identified by 18S, RNA as Candida tropicalis Y26 and Saccharomyces cerevisiae Y39. SHF processes by F94 and Y26 produced 45 gallon/ton rice straw while that of F98 and Y39 produced 50 gallon/ton rice straw.

\section{Keywords}

Bioethanol, Rice Straw, Different Pretreatments, Saccharomyces cerevisiae, Candida tropicalis,

*Corresponding author.

How to cite this paper: Abo-State, M.A., et al. (2014) Bioethanol Production from Rice Straw Enzymatically Saccharified by Fungal Isolates, Trichoderma viride F94 and Aspergillus terreus F98. Soft, 3, 19-29.

http://dx.doi.org/10.4236/soft.2014.32003 


\section{Separate Hydrolysis and Fermentation (SHF)}

\section{Introduction}

Increasing gas prices and environmental concerns, in recent years, have become the driving force for developing altersnative energy sources, especially fuel ethanol for automobiles [1].

Ethanol is a clean-burning renewable resource that can be produced from fermented cellulosic biomass [2]. Ethanol does not add to a net- $\mathrm{CO}_{2}$ atmospheric increase, thus there is no contribution to global warming. Combustion of ethanol results in relatively low emissions of volatile organic compounds, carbon monoxide and nitrogen oxides [3]. The importance of the biomass based ethanol production has undergone a huge increase in the last few years. However, further cost reduction is still essential for large deployment of this new technology. Since the cost of the traditionally used (sugar and starch-containing) raw materials represent the major part of the total production cost, constitutes about $40 \%-70 \%$ of the production cost [4], using less valuable materials, like agricultural waste, could reduce the expense significantly [5] [6].

Lignocellulosic materials represent a promising option as a feedstock for ethanol production considering their output/input energy ratio, their great availability both in tropical and temperate countries, their low cost (primarily related to their transport), and their ethanol yields. One of the advantages of the use of lignocellulosic biomass is that this feedstock is not directly related to food production. This implies the production of bioethanol without the need of employing vast extensions of fertile cultivable land for cropping cane or corn exclusively dedicated to the bioenergy production. In addition, lignocellulosics is a resource that can be processed in different ways for production of many other products like synthesis gas, methanol, hydrogen and electricity [7].

Rice straw is one of the abundant lignocellulosic waste materials in the world. It is annually produced in large quantity reaching about 731 million tons distributed in Africa (20.9 million tons), Asia (667.6 million tons), Europe (3.9 million tons) and America (37.2 million tons). This amount of rice straw can potentially produce 205 billion liters bioethanol per year, which is the largest amount from a single biomass feedstock [8].

Egypt is the largest rice producer in the Near East region, where rice cultivation area occupies over 1,080,000 feddan with an average farm yield of 4.76 tons/feddan and an approximate straw production of 2.4 tons/feddan [9].

Currently, the major practice to eliminate such massive amounts of post-harvest rice residues is field open air burning. Although field burning provides effective destruction of weed seeds and pathogenic microbial spores, the produced black smoke represents a threat to public health. In Egypt, rice cultivation and wood industries results in the accumulation of large quantities of agricultural wastes rich in cellulose, hemicellulose and lignin which are available with free cost throughout the year not only in farms but also in private homes [10].

Once these technological limitations are overcome, lignocellulosic biomass will be the main feedstock for ethanol production. Certainly, a detailed economic and environmental evaluation of the different feedstocks is required in order to make decisions on the most appropriate raw materials for fuel ethanol production in each case. A useful approach for performing such evaluations is to employ simulation tools based on realistic data obtained from existing ethanol production facilities, pilot plants or mathematical models. In addition, this approach allows the analysis of how different technological configurations (e.g., SHF or SSF) have influence on the indicators of the overall process. Examples of these comparative studies have been done [11] for corn and lignocellulosic ethanol [12] for sugar cane and corn ethanol, and for lignocellulosic biomass [13] [14].

Cellulose and hemi-cellulose, which are the principal biodegradable carbohydrate components of the bagasse, are found together with lignin in an intense cross linked, rigid ligno-cellulose complex [15]. This ligno-cellulosic structure severely limits the biological hydrolysis of cellulose and other polymers. Therefore, it requires pretreatment prior to hydrolysis [16] [17]. Industrially, the pretreated material is mainly thought to be hydrolyzed and fermented in two different steps: separate hydrolysis and fermentation (SHF), or in one single step: simultaneous saccharification and fermentation (SSF).

Most reports on ligno-cellulosic ethanol production involve acid hydrolysis followed by enzymatic saccharification [18]. The enzymatic saccharification step is cost-prohibitive because of the high cost of the enzymes.

The aim of this study is to examine different physical and enzymatical pretreatments of rice straw and the ability of isolated fungal strains to form fermentable sugars by secreting different cellulases through solid state 
fermentation process. The most promising fungal saccharification of rice straw hydrolysates was fermented by isolated yeast strains in a SHF process. Total bioethanol and sugar yields were evaluated to eventually predict the most satisfying SHF process.

\section{Materials and Methods}

\subsection{Collection and Preparation of Rice Straw}

Rice straw were collected from local market in Egypt, air-dried then chipped, grinded and sieved to size (0.5 - 1 $\mathrm{cm})$. Grinded materials were then stored in plastic bags at room temperature until analysis and treatment. Rice straw was initially analyzed for determination of hemi-cellulose, cellulose, and lignin contents.

\subsection{Isolation and Purification of Different Microorganisms}

According to Abo-State et al. [19] ten g of the grinded rice straw were added under aseptic conditions to $90 \mathrm{ml}$ sterile saline $(8.5 \mathrm{~g} / \mathrm{L} \mathrm{NaCl})$ in $250 \mathrm{ml}$ conical flasks. The flasks were shaken at $200 \mathrm{rpm}$ for $60 \mathrm{~min}$. After that, the suspensions were serially diluted $10^{-1}$ and cultured on Wickersham's (WH) agar medium [20] and potato dextrose agar (PDA) medium [21] plates for fungi and yeast, respectively. Yeast plates were incubated at $30^{\circ} \mathrm{C}$ for $48 \mathrm{~h}$. While fungi plates were incubated at $28^{\circ} \mathrm{C}$ for $7 \mathrm{~d}$. The well grown colonies were picked, streaked on sterile suitable medium for purification. Pure separated single colonies were maintained on sterile slants at $4^{\circ} \mathrm{C}$ for further investigation, and these slants were sub-cultured monthly. The selected isolates were preserved in micro-tubes containing 1:1 (v/v glycerol: pure isolate in appropriate medium) at $-4^{\circ} \mathrm{C}$.

\subsection{Screening for Microbial Utilization of Different Saccharides as Sole Carbon and Energy Sources}

All the isolated bacteria and yeast strains were streaked on minimal medium [22] supplemented with 1\% (W/V) of different saccharides; cellulose as model compound for polysaccharides; maltose, lactose, sucrose as model compounds for disaccharides; while glucose and xylose as model compounds for hexoses and pentoses monosaccharides, respectively.

\subsection{Spore Suspension Preparation}

According to Abo-State [23], the fungal isolates were inoculated onto $100 \mathrm{ml}$ PDA medium in $250 \mathrm{ml}$ Erlenmeyer flasks. The inoculated media were incubated at $28^{\circ} \mathrm{C}$ for $7 \mathrm{~d}$, and then the spores were collected by adding $30 \mathrm{ml}$ sterile saline containing $0.1 \%$ Tween- 80 . The spore suspension of each flask was collected in new sterile flask as stock for inoculation. The spore suspensions count was $\approx 4 \times 10^{7}$.

\subsection{Treatment of Rice Straw by Different Methods}

\subsubsection{Physical Pretreatment}

\section{1) Milling pretreatment}

According to Abo-State [23] ten gram of chipped and grinded rice straw was put into $250 \mathrm{ml}$ Erlenmeyer flask. It was then moistened with distilled water; the flasks were incubated for $2 \mathrm{~h}$ at room temperature. The solid material was then mixed vigorously with $100 \mathrm{ml}$ distilled water for extraction of soluble reducing sugars, then filtered with cloth sheets to separate the content into liquid and solid parts. The liquid filtrate was centrifuged at 10,000 rpm for $10 \mathrm{~min}$, and then, the content of total reducing sugars (TRS) was determined in clear supernatant by DNS method [24].

\section{2) Milling and autoclaving pretreatment}

Ten gram of chipped and grinded rice straw were put into $250 \mathrm{ml}$ Erlenmeyer flask then moistened with distilled water; the flasks were steam treated by autoclaving at $121^{\circ} \mathrm{C}$ and 1.5 bars for $20 \mathrm{~min}$. Then extraction, filtration and determination of (TRS) were performed as previously mentioned.

\section{3) Milling and Gamma $y$ irradiation pretreatment}

According to Abo-State [23], the chipped and grinded rice straw was exposed to different doses (50 and 70 Mrad) of $\gamma$ radiation (Indian cobalt-60 gamma cell at National Center for Radiation Research and Technology (NCRRT), Nasr City, Cairo, Egypt). Dose rate was $1 \mathrm{Mrad} / 120 \mathrm{~min}$ at the time of experiment. Ten g of each ir- 
radiated rice straw were put into $250 \mathrm{ml}$ Erlenmeyer flask, moistened with distilled water, incubated for $2 \mathrm{~h}$ at room temperature and then extraction, filtration and determination of TRS was performed as previously mentioned.

\section{4) Milling, $\gamma$ irradiation and autoclaving pretreatment}

Ten gram from chipped and grinded rice straw which exposed to different doses of $\gamma$ radiation were put into $250 \mathrm{ml}$ Erlenmeyer flask and moistened with distilled water, then autoclaved at $121^{\circ} \mathrm{C}$ and 1.5 bars for $20 \mathrm{~min}$, after the autoclaving period the flasks content were extracted, filtrated and TRS were determined by DNS method as mentioned before.

\subsubsection{Physical Pretreatment and Solid State Fermentation by Different Fungal Isolates}

Ten gram from chipped, grinded and autoclaved pretreated rice straw was inoculated with $2.0 \mathrm{ml}$ spore suspension from each pre-isolated fungal strains. The inoculated flasks were incubated statically at $30^{\circ} \mathrm{C}$ for $7 \mathrm{~d}$. After the incubation period the flasks were extracted and filtrated and then TRS were determined, as mentioned before. The monosaccharides concentrations for each hydrolysate were determined by HPLC. The percent saccharification was also calculated as described by Uma et al. [25] by the formula:

$$
\text { Saccharification } \%=\frac{\text { Formed } T R S \times 0.9 \times 100}{\text { Cellulose content of prtreated substrate }}
$$

\subsection{Bioethanol Production}

The production medium was formulated according to Yu and Zhang [26], where peptone (10.0 g/L), $\mathrm{KH}_{2} \mathrm{PO}_{4}$ $(2.0 \mathrm{~g} / \mathrm{L}), \mathrm{MgSO}_{4} \cdot 7 \mathrm{H}_{2} \mathrm{O}(1.0 \mathrm{~g} / \mathrm{L})$ were added to the hydrolysate obtained from most promising fungal isolates through solid state fermentation process and then sterilized by autoclaving at $121^{\circ} \mathrm{C}$ for $20 \mathrm{~min}$. The medium was inoculated with $10 \%(\mathrm{~V} / \mathrm{V})$ with pre-selected yeast isolates. The inoculated cultures were incubated at $30^{\circ} \mathrm{C}$ for $48 \mathrm{~h}$ at $150 \mathrm{rpm}$. After incubation, the fermented medium was centrifuged at 10,000 rpm for $10 \mathrm{~min}$. The produced ethanol and residual TRS concentrations were determined. The ethanol yield was calculated by the modified formula proposed by Gunasekaran and Kamini [27].

$$
\text { Ethanol yield } \%=\frac{\text { Produced ethanol } \times 100}{\text { Utilized } T R S}
$$

\subsection{Identification of Selected Isolates}

\subsubsection{Identification of Fungi}

Identification of the most promising selected fungal strains was performed according to Pitt and Hocking [28] at National Research Center, Dokki, Giza, Egypt, on the basis of cultural characters (colour, shape, surface and reverse pigmentation) as well as microscopical structure (septate or non septate hyphae, structure of hyphae and conidia).

\subsubsection{Identification of Yeasts}

However, the most potent selected yeast isolates were identified using $18 \mathrm{~S}$ ribosomal RNA (rDNA) amplification and sequencing, which was determined by direct sequencing of PCR-amplified $18 \mathrm{~S}$ rDNA. Genomic DNA isolation, amplification, and sequencing of the 18S rDNA gene, PCR purification and DNA sequencing were performed at Leaders Company, Cairo, Egypt. Blast program (http://www.ncbi.nlm.nih.gov/blast) was used to assay the DNA similarities.

\section{1) DNA extraction}

The yeast isolates were grown on Wickersham's agar plates at $28^{\circ} \mathrm{C}$ for 24 to $48 \mathrm{hr}$. A single colony was then sub cultured overnight on broth medium and incubated at $28^{\circ} \mathrm{C}$ with shaking at $200 \mathrm{rpm}$. DNA was extracted from this culture by an existing protocol [29]. The yeast nucleic acid precipitate was collected by pelleting in a microfuge, and the supernatant was decanted and discarded. The nucleic acid pellet was dried briefly under vacuum then re-suspended in $1 \mathrm{ml}$ of sterile water. DNA concentrations were determined spectrophotometrically with a spectrophotometer (Lambda 1A; Perkin-Elmer). DNA purity was determined by A260/A280 ratio and 1.8 to 2.1 was considered acceptable. 


\section{2) RAPD-PCR}

The two primers used in this study, forward primer NS6 (GCATCACAGACCTGTTATTGCCTC) and reveres primer NL4 (GGTCCGTGTTTCAAGACGG). Amplification reaction solutions were prepared in a final volume of $50 \mu \mathrm{l}$ containing $10 \mathrm{mM}$ Tris- $\mathrm{HCl}, \mathrm{pH} 8.3 ; 1.5 \mathrm{mM} \mathrm{MgCl}_{2} ; 50 \mathrm{mM} \mathrm{KCl}$; and $100 \mathrm{mM}$ each of dATP, dGTP, dCTP, and dTTP (Boehringer Mannheim), 2.5 M primer, 1.25 units of Taq DNA Polymerase (Boehringer Mannheim) and approximately 50 ng of DNA. The amplification was performed in an MJ Research programmable thermal cycler (PTC-100/60) where the program was as follows: universal denaturation cycle (5 min at $\left.94^{\circ} \mathrm{C}\right), 45$ cycles of annealing/extension reactions $\left(1 \mathrm{~min}\right.$ at $94^{\circ} \mathrm{C}, 1 \mathrm{~min}$ at an optimum annealing temperature $36^{\circ} \mathrm{C}$ for each used universal primer and 2 min at $\left.72^{\circ} \mathrm{C}\right)$ and cycle of final extension step $\left(5 \min\right.$ at $\left.72^{\circ} \mathrm{C}\right)$ was followed by soaking at $4^{\circ} \mathrm{C}$.

\section{3) Horizontal Gel Electrophoresis}

RAPD-PCR-amplified products were separated by agarose gel electrophoresis using a horizontal submarine gel system (E-C Apparatus Corp., Holbrook, NY). Agarose (Gibco BRL Life Technologies) at a concentration of $2 \%$ (wt/vol) was used to separate RAPD products. Electrophoresis was conducted in $0.5 \times$ TBE buffer (5.4 g of Tris base, $2.75 \mathrm{~g}$ of boric acid, and $2 \mathrm{ml}$ of $0.5 \mathrm{M}$ EDTA [pH 8.0] in 1 liter of distilled water) at $10 \mathrm{~V} / \mathrm{cm}$ for various times, depending on the size of the gel unit; DNA size markers (Boehringer XII and XIV) were used as standards. DNA bands were stained with ethidium bromide $(10 \mathrm{mg} / \mathrm{ml})$ and then visualized and photographed under UV light using a Gel Doc.2000 Transilluminator (Bio-Rad).

\section{4) Cluster analysis}

Genetic relationships and divergence between RAPD patterns of the yeast isolates were calculated from the Pearson coefficient using Bio-Rad Molecular Analyst software [30] and are illustrated in a dendrogram constructed using the un weighted pair-group method with arithmetic averaging (UPGMA) and single linkage. The DNA sequence homology was analysed in GenBank by means of the BLAST program. Phylogenic analysis was by use of CLCbio programme and the dendograms drawn with UPGMA algorithm and bootstrap with 100 replicates.

\subsection{Analytical Methods}

\subsubsection{Analysis of Chemical Composition of Rice Straw}

Hemi-cellulose, cellulose, and lignin concentrations in rice straw samples before and after hydrolysis were determined in Agricultural Research Center, Giza, Egypt.

\subsubsection{HPLC Analysis of Sugars}

The mono-saccharides were determined and quantified before and after fermentation at National Research Center, Giza, Egypt, according to the method reported by Askar et al. [31], by High Performance Liquid Chromatography (HPLC) equipped with 10A Shimadzu Shim-pack SCR-101N column $(7.9 \mathrm{~mm} \times 30 \mathrm{~cm})$, using de-ionized water as the mobile phase (flow rate $0.5 \mathrm{~mL} / \mathrm{min}$ at $40^{\circ} \mathrm{C}$ ) and refractive index detector. The injected volume was $20 \mu \mathrm{L}$. Sugar standards were used for quantification of different sugars (glucose, xylose, mannose, galactose, arabinose and rhamnose) in the samples.

\subsubsection{GC Chromatographic Analysis of Bioethanol}

Ethanol production was analyzed by gas chromatography (model 6890, Agilent), equipped with flam ionization detector and $(60 \mathrm{~m} \times 530 \mu \mathrm{m} \times 5.00 \mu \mathrm{m})$ nominal capillary column. Helium was the carrier gas, flow rate was $25 \mathrm{~mL} / \mathrm{min}$. Oven and detector temperature was $300^{\circ} \mathrm{C}$.

\subsubsection{Determination of Total Reducing Sugar}

Total reducing sugars ware determined by 3,5-dinitro salicylic acid DNS method [23] and glucose was used as standard. The samples were stored in a fridge at $-18^{\circ} \mathrm{C}$ until analysis to prevent spoilage by microbes and loss of ethanol.

\section{Results and Discussion}

\subsection{Isolation of Different Microbial Isolates}

Eight microbial isolates, five yeast (Y25, Y26, Y90, Y97 and Y98) and three fungi (F68, F94 and F98), were 
isolated from rice straw and differentiated according to their morphological and microscopically examination.

\subsection{Screening for the Ability of Yeast Isolates to Utilize Different Saccharides}

Yeast isolates showed different ability to utilize cellulose and different sugars as listed in Table 1. Yeast isolates (Y26 and Y39) were selected for further study as they showed the highest efficiency for utilization of different saccharides as indicated in Table 1.

\subsection{Identification of Selected Yeast Isolates}

DNA was isolated from the two selected yeast isolates (Y26 and Y39), then amplified using RAPD-PCR producing 18S rRNA gene it was 1800 bp in case of isolate Y26 and $1850 \mathrm{bp}$ in case of isolate Y39, then separated using gell electrophoresis. The two genes gell bands were cutted and purified from agarose to be ready for sequencing step.

The DNA sequence homology was analyzed in Gen Bank by means of Blast program (http://www.ncbi.nlm.nih.gov/blast) for assay the DNA similarities.

The two yeast isolates Y26 and Y39 were identified as Candida tropicalis Y26 with similarity of 98\% and Saccharomyces cerevisiae Y39, with similarity of 94\% respectively.

\subsection{Effect of Different Pretreatment on Total Reducing Sugar Yield}

The Total reducing sugars (TRS) yields give estimation of how much of the sugars can be liberated during hydrolysis. It is actually the most important yield since it deals with all process steps from the raw rice straw to fermentable sugars. The applied physical pretreatments showed different effects on total reducing sugar (TRS) yield as indicated in Table 2 . The chipped and grinded rice straw (milling pretreatment) yielded the lowest concentration of TRS $1.44 \mathrm{~g} / \mathrm{L}$ with saccharification of 3.72\%, followed by the milling + autoclaving which form highest concentration of TRS $6.35 \mathrm{~g} / \mathrm{L}$ with saccharification of $16.42 \%$, The treatment of milling rice straw and $\gamma$ irradiation at dose of 50 Mrad showed yield of TRS slightly higher than that of steam pretreatment, recording $6.62 \mathrm{~g} / \mathrm{L}$ with saccharication of $17.12 \%$. Increasing the dose of $\gamma$ irradiation to $70 \mathrm{Mrad}$ decreased the TRS yield to $5.03 \mathrm{~g} / \mathrm{L}$ with saccharification of $13.01 \%$.

Table 1. Screening for the ability of yeast isolates to utilize different saccharides.

\begin{tabular}{|c|c|c|c|c|c|c|}
\hline \multirow{2}{*}{\multicolumn{2}{|c|}{ Saccharides }} & \multicolumn{5}{|c|}{ Yeast isolates } \\
\hline & & \multirow{2}{*}{$\begin{array}{l}\text { Y26 } \\
+++\end{array}$} & \multirow{2}{*}{$\begin{array}{l}\text { Y39 } \\
+++\end{array}$} & \multirow{2}{*}{$\begin{array}{l}\text { Y90 } \\
+++\end{array}$} & \multirow{2}{*}{$\begin{array}{l}\text { Y97 } \\
+++\end{array}$} & \multirow{2}{*}{$\begin{array}{c}\text { Y98 } \\
++\end{array}$} \\
\hline & Glucose & & & & & \\
\hline \multirow[t]{3}{*}{ Mono- } & Xylose & ++ & ++ & ++ & ++ & + \\
\hline & Arabinose & ++ & ++ & ++ & ++ & + \\
\hline & Maltose & +++ & +++ & +++ & +++ & ++ \\
\hline \multirow[t]{2}{*}{ Di- } & Lactose & +++ & ++ & ++ & ++ & ++ \\
\hline & Sucrose & ++ & ++ & ++ & ++ & ++ \\
\hline Poly- & Cellulose & + & + & + & - & - \\
\hline
\end{tabular}

- ve (no growth), + ve (moderate growth), ++ ve (good growth), +++ ve (very good growth).

Table 2. Total reducing sugars (TRS) from rice straw after different pretreatments.

\begin{tabular}{|c|c|c|c|c|}
\hline & Different treatment & & TRS g/L & Saccharification \% \\
\hline \multirow{6}{*}{ Physical } & Milling & & 1.44 & 3.72 \\
\hline & \multirow{3}{*}{ Milling $+\gamma$ irradiation } & & 6.35 & 16.42 \\
\hline & & 50 & 6.62 & 17.12 \\
\hline & & 70 & 5.03 & 13.01 \\
\hline & \multirow{2}{*}{ Milling + autoclaving $+\gamma$ irradiation } & 50 & 11.23 & 29.04 \\
\hline & & 70 & 12.15 & 31.42 \\
\hline \multirow{3}{*}{$\begin{array}{l}\text { Physical + solid state } \\
\text { fermentation }\end{array}$} & F68 & & 12.62 & 33.04 \\
\hline & F94 & & 13.58 & 35.12 \\
\hline & F98 & & 17.00 & 44.06 \\
\hline
\end{tabular}


Applying milling+ autoclaving $+\gamma$ irradiation treatments to rice straw increased the TRS yield to 11.23 and $12.15 \mathrm{~g} / \mathrm{L}$ with saccarification of $29.04 \%$ and $31.42 \%$ with $\gamma$ irradiation dosage of $50 \mathrm{Mrad}$ and $70 \mathrm{Mrad}$, respectively. These results were in agreement with that recorded by Abostate [23].

According to Helal [32], ionizing radiation as $\gamma$ lowers the degree of the polymerization of cellulose and lignin and partially disrupts the ligno-cellulosic complex.

Although steam pretreatment by autoclaving used for sterilization has affected and resulted in an increase in TRS. With fungal treatment more increase in the yield of sugars were observed, where, the highest production of TRS was obtained by fungal treatments; F66, F94 or F98 producing 12.62, 13.58 and $17.00 \mathrm{~g} / \mathrm{L}$ with \% saccharification of 33.04\%, 35.12\% and 44.06\%, respectively as indicated in Table 2.

The filtrate (hydrolyzate) produced from solid state fermentation by F94 and F98 which have shown the highest TRS yield were used for further fermentation through SHF process. F94 and F98 were identified as Trichoderma viride F94 and Aspergillus terreus F98, respectively.

It is obvious from this study that, mechanical pretreatment by lowering the size of rice straw and physical steam treatment with autoclaving could change the structure of the lignocellulosic material or even simply affect the lignin hemi-cellulose and cellulose (LHC) complex and thus facilitate the growth of fungi with high cellulolytic activity as recorded by Abo-state [23].

Thes results have been confirmed by the results of Helal [32]; pretreatment before fungal hydrolysis increases the surface area of the cellulose by reducing particle size.

\subsection{Chemical Composition of Rice Straw before and after Microbial Saccharification}

According to Irfan et al. [33], weight loss during treatment represents the degradation of ligno-cellulosic biomass. Table 3 showed hemi-cellulose, cellulose and lignin content in untreated rice straw was $31.22 \%$, 34.80\% and $10.18 \%$ (wt\%), respectively, while the chemical composition of treated rice straw after saccharication by Trichoderma viride F94 was 19.22\%, 25.20\% and 7.52\% (wt\%), respectively and after hydrolysis by Aspergillus terreus $\mathrm{F} 98$ was $15.03 \%, 20.70 \%$ and $6.73 \%$ (wt\%), respectively.

Microbial treatment with A. terreus F98 led to higher delignification of rice straw than that of $T$. viride F94 recording $34 \%$ and $26 \%$, respectively as indicated in Table 3 .

A. terreus F-98 expressed higher celluolytic activities than that of $T$. viride F94 recording decrease in hemicellulose content by $52 \%$ and $38 \%$, respectively, and recorded a decrease of $41 \%$ and $28 \%$, respectively for cellulose content.

Abo-state et al. [23] [34] reported that Aspergillus terreus MAM-F23 produced the highest CMCase (309 $\mathrm{U} / \mathrm{ml}$ ) on rice straw and also produced avicellase and FPase more than $T$. veride.

The tow fungal isolates $T$. viride F94 and A. terreus F98 have the ability to degrade hemi-cellulose more than that of cellulose and lignin as indicated in Table 3.

\subsection{Production of Ethanol by Isolated Yeasts through SHF Process of the Obtained Hydrolysates}

Evaluation of ethanol production is necessary to quantify the process final performance. In this study; the hydrolysates resulted from saccharification of rice straw by Trichoderma viride F94 and Aspergillus terreus F98 were used for fermentation by yeast isolates. The most potent strains in bioethanol production Y26 and Y39 have been chosen for further studies and identification. The most potent strains Y26 and Y39 were used to ferment the hydrolysate resulted from F94 and F98 to produce ethanol as indicated in Table 4. The best ethanol yield was obtained from hydrolysate of Aspergillus terreus F98 after fermentation by S. cerevisiae Y39 recording $15.25 \mathrm{~g} / \mathrm{L}$ followed by that obtained with SHF process using T. viride F94 and Candida tropicalis Y26 recording $12.86 \mathrm{~g} / \mathrm{L}$, with ethanol yield of $89.71 \%$ and $75.65 \%$, respectively. The difference in performance

Table 3. Chemical composition of rice straw before and after hydrolyses by T. viride F94 and A. terreus F98.

\begin{tabular}{|c|c|c|c|}
\hline Sample & Hemi-cellulose \% & Cellulose \% & Lignin \% \\
\hline Before hydrolyses & 31.22 & 34.80 & 10.18 \\
\hline After hydrolyses by T. viride F94 & 19.22 & 25.20 & 7.52 \\
\hline After hydrolyses by A. terreus F98 & 15.03 & 20.70 & 6.73 \\
\hline
\end{tabular}


Table 4. The concentration and yield of ethanol produced from fermentation of rice straw by the most promising yeast isolates after pretreatment and hydrolysis by T. viride F94 and A. terreus F98.

\begin{tabular}{lccccc}
\hline & \multicolumn{3}{c}{ Fungal isolates } \\
\cline { 2 - 6 } Yeast isolates & \multicolumn{3}{c}{ T. viride F94 } & A. terreus F98 \\
\cline { 2 - 6 } & EC g/L & $\mathbf{E Y \%}$ & 11.28 & 66.35 \\
C. tropicalis Y26 & $\mathbf{1 2 . 8 6}$ & 75.65 & $\mathbf{1 5 . 2 5}$ & $\mathbf{8 9 . 7 1}$ \\
S. cerevisiae Y39 & 11.54 & $\mathbf{6 7 . 8 8}$ &
\end{tabular}

EC: ethanol concentration; EY: ethanol yield.

among the yeast strains may be due to preferential utilization of pentose and hexose sugars prevailing in the hydrolysate. Also, it may be strain dependent.

Srilekha Yadav et al. [35] reported batch fermentation of pretreated rice straw hydrolysate with $31 \mathrm{~g} / \mathrm{L}$ TRS, ethanol of $12 \mathrm{~g} / \mathrm{L}$ after $36 \mathrm{~h}$ incubation with a yield of $0.4 \mathrm{~g} / \mathrm{g}$ and productivity of $0.33 \mathrm{~g} / \mathrm{L} / \mathrm{h}$ by co-culture of Saccharomyces cerevisiae and Pichia stipitis

Kumar and puspha [36] reported fungal pretreatment of rice straw by fungal strains T. ressi and A. awamori in $\mathrm{SmF}$ at 5days of incubation at $30^{\circ} \mathrm{C}$ produced TRS of 73.7 and $62.7 \mathrm{mg} / \mathrm{g}$, respectively. Ethanol yield after the whole SmF process of 12 days by Zymomonas mobilis strain amounted to $\approx 8.7,7.9 \mathrm{~g} / \mathrm{L}$, respectively.

Similar observation were reported by Patel et al. [37] where grinding + autoclaving has resulted in release of sugars and with fugal treatment still increase in the release of sugars were observed because of the enzymatic hydrolysis of celluloses carried out by the enzymes from fungi. The yield of TRS produced after $5 \mathrm{~d}$ of solid state fermentation by Aspergillus awamori, Asperigillus niger, Trichoderma reesei and Trichoderma viride was $\approx 38,43,64$ and $51 \mathrm{mg} / \mathrm{g}$, respectively. Ethanol yield after the whole SHF process of $8 \mathrm{~d}$. using $S$. cerevisiae recorded $\approx 4,3$, 4 and $6 \mathrm{~g} / \mathrm{L}$ while for Candida shehatae recorded $\approx 4,3,3$ and $5 \mathrm{~g} / \mathrm{L}$, respectively.

Zayed and Meyer [38] reported that; both $T$. viride and A. niger are able to liberate sugars from different kinds of cellulose waste materials.

\subsection{Determination of the Reducing Sugars before and after Fermentation}

The residual reducing sugars content decreased significantly after fermentation as shown in Table 5. This indicates the ability of Candida tropicalis Y26 and Saccharomyces cerevisiae Y39 to utilize available reducing sugars.

\subsection{Determination of Monosaccharides before and after Fermentation}

The saccharification of rice straw with $T$. viride F94 afforded the following: glucose $(6.99 \mathrm{~g} / \mathrm{L})$, xylose $(3.10 \mathrm{~g} / \mathrm{L})$ Rhamnose $(1.59 \mathrm{~g} / \mathrm{L})$ and arabinose $(1.5 \mathrm{~g} / \mathrm{L})$. While the saccharification of rice straw with $A$. terreus $\mathrm{F} 98$ led to glucose $(10.59 \mathrm{~g} / \mathrm{L})$, xylose $(7.51 \mathrm{~g} / \mathrm{L})$, rhamnose $(1.10 \mathrm{~g} / \mathrm{L})$ and arabinose $(0.49 \mathrm{~g} / \mathrm{L})$ as indicated in Table 6 and Table 7. In this study, not all kinds of sugars detected in hydrolysates were completely consumed. However, the yeast strains under study fermented both gluscose and xylose to ethanol. It was noticed that glucose, arabinose and rhamnose were completely consumed while Lower consumption of xylose $(\approx 77 \%)$ was recorded in SHF by SHF using T. viride F94 and Candida tropicalis Y26 as shown in Table 6. In case of SHF using Aspergillus terreus F98 and Saccharomyces cerevisiae Y39, only complete consumption was recorded for glucose and rhamnose, while xylose and arabinose recorded nearly the same consumption, $\approx 57 \%$ and $59 \%$, respectively as indicated in Table 7.

The conventional alcohol fermenting organism, Saccharomyces cerevisiae can ferment only hexose sugars to ethanol [39] [40]. Among xylose fermenting yeasts, Pachysolent annophilus [41] Pichia stipities [42], Candida tropicalis [43] are promising for ethanol production.

It has been reported by Girio et al. [44] and [45] that evaluation of ethanol production is necessary to quantify the process final performance. At industrial level, only glucose is being fermented with high ethanol production yields while xylose fermentation, which is also essential for the economical success of lignocellulosic ethanol, continues being investigated to raise the low yields obtained so far.

Thus the ability of the locally isolated Candida tropicalis Y26 and Saccharomyces cerevisiae Y39 to ferment glucose and xylose in the obtained hydrolysates to ethanol is great advantage. 
Table 5. Total reducing sugars (TRS) of rice straw hydrolyzate before and after fermentation by selected yeast isolates.

\begin{tabular}{|c|c|c|c|c|}
\hline \multirow{2}{*}{ Fungal isolates } & \multicolumn{3}{|c|}{ TRS (g/L) } & \multirow{2}{*}{ E.C $\mathrm{g} / \mathrm{L}$} \\
\hline & Before fermentation & After fern & & \\
\hline \multirow{2}{*}{ T. viride F94 } & \multirow{2}{*}{15.97} & C. tropicalis Y26 & 2.28 & 12.85 \\
\hline & & S. cerevisiae Y39 & 3.22 & 10.54 \\
\hline \multirow{2}{*}{ A. terreus F98 } & \multirow{2}{*}{17.01} & C. tropicalis Y26 & 3.99 & 11.28 \\
\hline & & S. cerevisiae Y39 & 1.76 & 15.36 \\
\hline
\end{tabular}

E.C: Ethanol Concentration (g/L).

Table 6. Concentration of mono-saccharides found in rice straw hydrolysate resulted from hydrolysis by T. viride F94 and after fermentation by C. tropicalis Y26.

\begin{tabular}{cccc}
\hline Monosaccharides & After hydrolysis $\mathbf{g} / \mathbf{L}$ & After fermentation $\mathbf{g} / \mathbf{L}$ & Consumption \% \\
\hline Rhamnose & 1.59 & 0.00 & 100 \\
Xylose & 3.10 & 0.70 & 77.42 \\
Glucose & 6.99 & 0.00 & 100 \\
Arabinose & 1.50 & 0.00 & 100 \\
\hline
\end{tabular}

Table 7. Concentration of mono-saccharides found in rice straw hydrolysate resulted from hydrolysis by A. terreus F98 and after fermentation by S. cerevisiae Y39.

\begin{tabular}{cccc}
\hline Monosaccharides & After hydrolysis $\mathbf{g} / \mathbf{L}$ & After fermentation $\mathbf{g} / \mathbf{L}$ & Consumption \% \\
\hline Rhamnose & 1.10 & 0.0 & 100 \\
Xylose & 7.51 & 3.23 & 56.99 \\
Glucose & 10.59 & 0.0 & 100 \\
Arabinose & 0.49 & 0.20 & 59.18 \\
\hline
\end{tabular}

Senthilgura et al. [46] reported that, cellulose hydrolysis yields glucose which can be readily fermented with many existing organisms. Hemi-cellulose hydrolysis produces both hexoses and pentoses (manose, galactose, xylose and arabinose) that are not all fermented with exiting strains.

\section{Conclusion}

Generally sacchaification step is carried out by commercially available cellulase enzymes which are very expensive. This preliminary study showed that ethanol production (second generation of bioethanol) from rice straw is possible by intact fungal organisms as source of cellulase enzymes through solid state fermentation using $T$. viride F94 and A. terreus F98. This was followed by hydrolysate fermentation by C. tropicalis Y26 and S. cerevisiae Y39 through separate hydrolysis and fermentation (SHF) process. The use of rice straw is cheap, renewable source of energy (fermentable sugars) to produceethanol via sustinable technology promise with great future. The ethanol yield in our study was 50 and 45 gallon/ton, respectively. This ethanol yield was 2.42 and 2.44 times lower than the theoretical yield (109.9 gallon/ton) as per National Renewable Energy Laboratory (NREL) calculation, which can be seen at (http://www1.eere.energy.gov/biomass/ethanol yield calculation.html). In this study, a significant removal of lignin from rice straw was achieved through eco-friendly process, which resulted in high production of ethanol. Further research is needed to optimize the condition for maximum production of ethanol from rice straw.

\section{References}

[1] Moiser, N., Wyman, C., Dale, B., Elander, R., Lee, Y.Y. and Holtzapple, M. (2005) Features of Promising Technologies for Pretreatment of Lignocellulosic Biomass. Bioresource Technology, 96, 673-686. http://dx.doi.org/10.1016/j.biortech.2004.06.025

[2] Masud, H.Sk., Anantharaman, N. and Manas, D. (2012) Bioethanol Fermentation from Untreated and Pretreated Lig- 
nocellulosic Wheat Straw Using Fungi Fusarium oxysporum. Indian Journal of Chemical Technology, 19, 63-70.

[3] Park, I., Kim, I., Kang, K., Sohn, H., Rhee, I., Jin, I. and Jang, H. (2010) Cellulose Ethanol Production from Waste Newsprint by Simultaneous Saccharification and Fermentation Using Saccharomyces cerevisiae KNU5377. Process Biochemistry, 45, 487-492. http://dx.doi.org/10.1016/j.procbio.2009.11.006

[4] Claassen, P.A.M., Van Lier, J.B., Lopez Contreras, A.M., Van Niel, E.W., Sijtsma, L., Stams, A.J.M., de Vries, S.S. and Weusthuis, R.A. (1999) Utilization of Biomass for the Supply of Energy Carriers. Applied Microbiology and Biotechnology, 52, 741-755. http://dx.doi.org/10.1007/s002530051586

[5] Manjunath, S.G. and Geeta, G.S. (2007) Effectiveness of Fungal Pretreatment of Agro Residues on Ethanol Production by Yeasts and Zymomonas mobilis. Karnataka Journal of Agricultural Sciences, 20, 301-304.

[6] Rabelo, S.C., Carrere, H., Maciel Filho, R. and Costa, A.C. (2011) Production of Bioethanol, Methane and Heat from Sugarcane Bagasse in a Biorefinery Concept. Bioresource Technology, 102, 7887-7895. http://dx.doi.org/10.1016/j.biortech.2011.05.081

[7] Chum, H.L. and Overend, R.P. (2001) Biomass and Renewable Fuels. Fuel Processing Technology, 71, 187-195. http://dx.doi.org/10.1016/S0378-3820(01)00146-1

[8] Karimi, K., Emtiazi, G. and Taherzadeh, M.J. (2006) Ethanol Production from Dilute Acid Pretreated Rice Straw by Simultaneous Saccharification and Fermentation with Mucor indicus, Rhizopus oryzae, and Saccharomyces cerevisiae. Enzyme and Microbial Technology, 40, 138-144. http://dx.doi.org/10.1016/j.enzmictec.2005.10.046

[9] Sabaa, M.F. and Sharaf, M.F. (2000) Egyptian Policies for Rice Development. Cahiers Options Mediterraneennes, 40, 25-36.

[10] Sherief, A.A., El-Tanash, A.B. and Temraz, A.M. (2010) Lignocellulolytic Enzymes and Substrate Utilization during Growth and Fruiting of Pleurotus ostreatus on Some Solid Wastes. Journal of Environmental Science and Technology, 3, 18-34. http://dx.doi.org/10.3923/jest.2010.18.34

[11] McAloon, A., Taylor, F., Yee, W., Ibsen, K. and Wooley, R. (2000) Determining the Cost of Producing Ethanol from Corn Starch and Lignocellulosic Feedstocks. Technical Report NREL/TP-580-28893.

[12] Quintero, J.A., Montoya, M.I., Sánchez, O.J., Giraldo, O.H. and Cardona, C.A. (2007) Fuel Ethanol Production from Sugarcane and Corn: Comparative Analysis for a Colombian Case. Energy.

[13] Aden, A., Ruth, M., Ibsen, K., Jechura, J., Neeves, K., Sheehan, J., Wallace, B., Montague, L., Slayton, A. and Lukas, J. (2002) Lignocellulosic Biomass to Ethanol Process Design and Economics Utilizing Concurrent Dilute Acid PreHydrolysis and Enzymatic Hydrolysis for Corn Stover. Technical Report NREL/TP-510-32438, National Renewable Energy Laboratory, Golden, 143 p. http://dx.doi.org/10.2172/15001119

[14] Sánchez, O.J., Fraga, E.S. and Cardona, C.A. (2006) Process Synthesis for Fuel Ethanol Production from Lignocellulosic Biomass Using an Optimization-Based Strategy. World Renewable Energy Congress IX and Exhibition, Florence.

[15] Mutalik, S., Vinodkumar, C.S., Swamy, S. and Manjappa, S. (2011) Depolymerization of Bagasse by Ruminococcus albus in the Production of Eco-Friendly Fuel. Research in Biotechnolgy, 2, 1-6.

[16] Patel, J., Seema, D., Ronkarappa, R. and Shobha, K.S. (2007) Fungal Pretreatment Studies on Rice Husk and Bagasse for Ethanol Production. Electronic Journal of Environmental, Agricultural and Food Chemistry, 6, 1921-1926.

[17] Goshadrou, A., Karimi, K. and Taherzadeh, M.J. (2001) Bioethanol Production from Sweet Sorghum Bagasse by Mucor hiemalis. Industrial Crops and Products, 34, 1219-1225.

[18] Martín, C., Galbe, M., Wahlbom, C.F., Hahn-Hägerdal, B. and Jönsson, L.J. (2002) Ethanol Production from Enzymatic Hydrolysates of Sugarcane Bagasse Using Recombinant Xylose-Utilizing Saccharomyces cerevisiae. Enzyme and Microbial Technology, 31, 274-282. http://dx.doi.org/10.1016/S0141-0229(02)00112-6

[19] Abo-State, M.A.M., Hammad, A.I., Swelim, M. and Gannam, R.B. (2010) Enhanced Production of Cellulase (s) by Aspergillus spp. Isolated from Agriculture Wastes by Solid State Fermentation. American-Eurasian Journal of Agricultural \& Environmental Sciences, 8, 402-410.

[20] Wickerhams, L.J. (1951) Taxonomy of Yeasts. US Department of Agriculture, Washington DC, Technical Bulletin No.1029, 1-56.

[21] Oxoid (1982) Manual of Culture Media, Ingredients and Other Laboratory Services. Oxoid Limited, Basingstoke.

[22] Bahkali, A.H. (1995) Production of Cellulase, Xylanase and Polygalacturonase by Verticillium tricorpusaon on Different Substrates. Bioresource Technology, 51, 171-174. http://dx.doi.org/10.1016/0960-8524(94)00110-M

[23] Abo-State, M.A.M. (2003) Production of Carboxymethyl Cellulase by Fusarium oxysporium and Fusarium neoceros from Gamma-Pretreated Lignocellulosic Wastes. Egyptian Journal of Biotechnology, 15, 151-168.

[24] Miller, G.L. (1959) Use of Dinitrosalicylic Acid Reagent for the Determination of Reducing Sugars. Analytical Chemistry, 31, 426-428. http://dx.doi.org/10.1021/ac60147a030

[25] Uma, C., Muthulakshmi, C., Gomathi, D. and Gopalakrishnan, V.K. (2010) Fungal Invertase as Aid for Production of 
Ethanol from Sugarcane Bagasse. Research Journal of Microbiology, 5, 980-985. http://dx.doi.org/10.3923/jm.2010.980.985

[26] Yu, Z.S. and Zhang, H.X. (2004) Ethanol Fermentation of Acid-Hydrolyzed Cellulosic Pyrolysate with Saccharomyces cerevisiae. Bioresource Technology, 93, 199-204. http://dx.doi.org/10.1016/j.biortech.2003.09.016

[27] Gunasekaran, P. and Kamini, N.R. (1991) High Ethanol Productivity from Lactose by Immobilized Cells of Kluyveromyces fragilis and Zymomonas mobilis. World Journal of Microbiology and Biotechnology, 7, 551-556. http://dx.doi.org/10.1007/BF00368359

[28] Pitt, J.I. and Hocking, A.D. (1997) Fungi and Food Spoilage. 2nd Edition, Blacki Academic Press, London. http://dx.doi.org/10.1007/978-1-4615-6391-4

[29] Lehmann, P.F., Lin, D. and Lasker, B.A. (1992) Genotypic Identification and Characterization of Species and Strains within the Genus Candida by Using Random Amplified Polymorphic DNA. Journal of Clinical Microbiology, 30, 3249-3254.

[30] Anonymous (1999) Molecular Analyst Software, Fingerprinting Plus and Fingerprinting DST Software, Version 1.6, Instruction Manual. Bio-Rad Laboratories, Life Science Group, Hercules, Calif.

[31] Askar, M.M.S., Youssri, M., Ahmed, F. and Ramadan, M. (2009) Chemical Characteristics and Antioxidant Activity of Exopolysaccharide Fractions from Microbacterium terregens. Carbohydrate Polymers, 77, 563-567. http://dx.doi.org/10.1016/j.carbpol.2009.01.037

[32] Helal, A.G. (2006) Bioconversion of Straw into Improved Fodder: Preliminary Treatment of Rice Straw Using Mechanical, Chemical and/or Gamma Irradiation. Mycobiology, 34, 14-21. http://dx.doi.org/10.4489/MYCO.2006.34.1.014

[33] Irfan, M., Gulsher, M., Abbas, S., Syed, Q., Nadeem, M. and Baig, S. (2011) Effect of Various Pretreatment Conditions on Enzymatic Saccharification. Songklanakarin Journal of Science \& Technology, 33, 397-404.

[34] Abo-State, M.A.M., Hammad, A.I., Swelim, M. and Gannam, R.B. (2010) Some Critical Factors Affecting Cellulase(s) Production by Aspergillus terreus MAM-F23 and Aspergillus flavus MAM-F35 under Solid-State Fermentation of Wheat Straw. World Applied Sciences Journal, 9, 1171-1179.

[35] Srilekha Yadav, K., Naseeruddin, S., Prashanthi, G., Sateesh, L. and Venkateswar, R. (2011) Bioethanol Fermentation of Concentrated Rice Straw Hydrolysate Using Co-Culture of Saccharomyces cerevisiae and Pichia stipitis. Bioresource Technology, 102, 6473-6478. http://dx.doi.org/10.1016/j.biortech.2011.03.019

[36] Kumar, S.A. and Pushpa, A. (2012) Saccharification by Fungi and Ethanol Production by Bacteria Using Lignocellulosic Materials. International Research Journal of Pharmacy, 3, 411-414.

[37] Patel, S.J., Onkarappa, R. and Gurumurthy, S.B. (2012) Ethanol Production from Lignocelluloses Hydrolyzates by Different Yeasts. Asian Journal of Experimental Biological Sciences, 3, 350-354.

[38] Zayed, G. and Meyer, O. (1996) The Single-Batch Bioconversion of Wheat Straw to Ethanol Employing the Fungus Trichoderma viride and the Yeast Pachysolen tannophylu. Applied Microbiology and Biotechnology, 45, 551-555.

[39] Alfenore, C., Molina, C., Guillouet, S.E., Uribelarrea, J.L., Goma, G. and Benbadis, L. (2002) Improving Ethanol Production and Viability of Saccharomyces cerevisiae by a Vitamin Feeding Strategy during Fed Batch Process. Applied Microbiology and Biotechnology, 60, 67-72. http://dx.doi.org/10.1007/s00253-002-1092-7

[40] Mutalik, S., Vinodkumar, C.S., Swamy, S. and Manjappa, S. (2011) Depolymerization of Bagasse by Ruminococcus albus in the Production of Eco-Friendly Fuel. Research in Biotechnology, 2, 1-6.

[41] Cheng, K.K., Cai, Y.B., Zhang, A.J., Ling, Z.H., Zhou, J.Y., Ge, P.J. and Xu, M.J. (2008) Sugarcane Bagasse Hemicellulose Hydrolysate for Ethanol Production by Acid Recovery Process. Biochemical Engineering Journal, 38, 105109. http://dx.doi.org/10.1016/j.bej.2007.07.012

[42] Nigam, N.J. (2001) Ethanol Production from Wheat Straw Hemicelluloses Hydrolysate by Pichia stipitis. Journal of Biotechnology, 87, 17-27. http://dx.doi.org/10.1016/S0168-1656(00)00385-0

[43] Jeffries, T.W. (1981) Conversion of Xylose to Ethanol under Aerobic Conditions by Candida tropicalis. Biotechnology Letters, 3, 213-218. http://dx.doi.org/10.1007/BF00154647

[44] Girio, F.M., Fonseca, C., Carvalheiro, F., Duarte, L.C., Marques, S. and Bogel-Lukasik, R. (2010) Hemicelluloses for Fuel Ethanol: A Review. Bioresource Technology, 101, 4775-4800. http://dx.doi.org/10.1016/j.biortech.2010.01.088

[45] Salvachua, D., Prieto, A., Lopez-Abelairas, M., Lu-Chau, T., Martinaz, A.T. and Martinez, M.J. (2011) Fungal Pretreatment: An Alternative in Second-Generation Ethanol from Wheat Straw. Bioresource Technology, 102, 7500-7506. http://dx.doi.org/10.1016/j.biortech.2011.05.027

[46] Senthilguru, K., George, T., Vasanthi, N. and Kannan, K. (2011) Ethanol Production from Lignocellulosic Waste. World Journal of Science and Technology, 1, 12-16. 
Scientific Research Publishing (SCIRP) is one of the largest Open Access journal publishers. It is currently publishing more than 200 open access, online, peer-reviewed journals covering a wide range of academic disciplines. SCIRP serves the worldwide academic communities and contributes to the progress and application of science with its publication.

Other selected journals from SCIRP are listed as below. Submit your manuscript to us via either submit@scirp.org or Online Submission Portal.
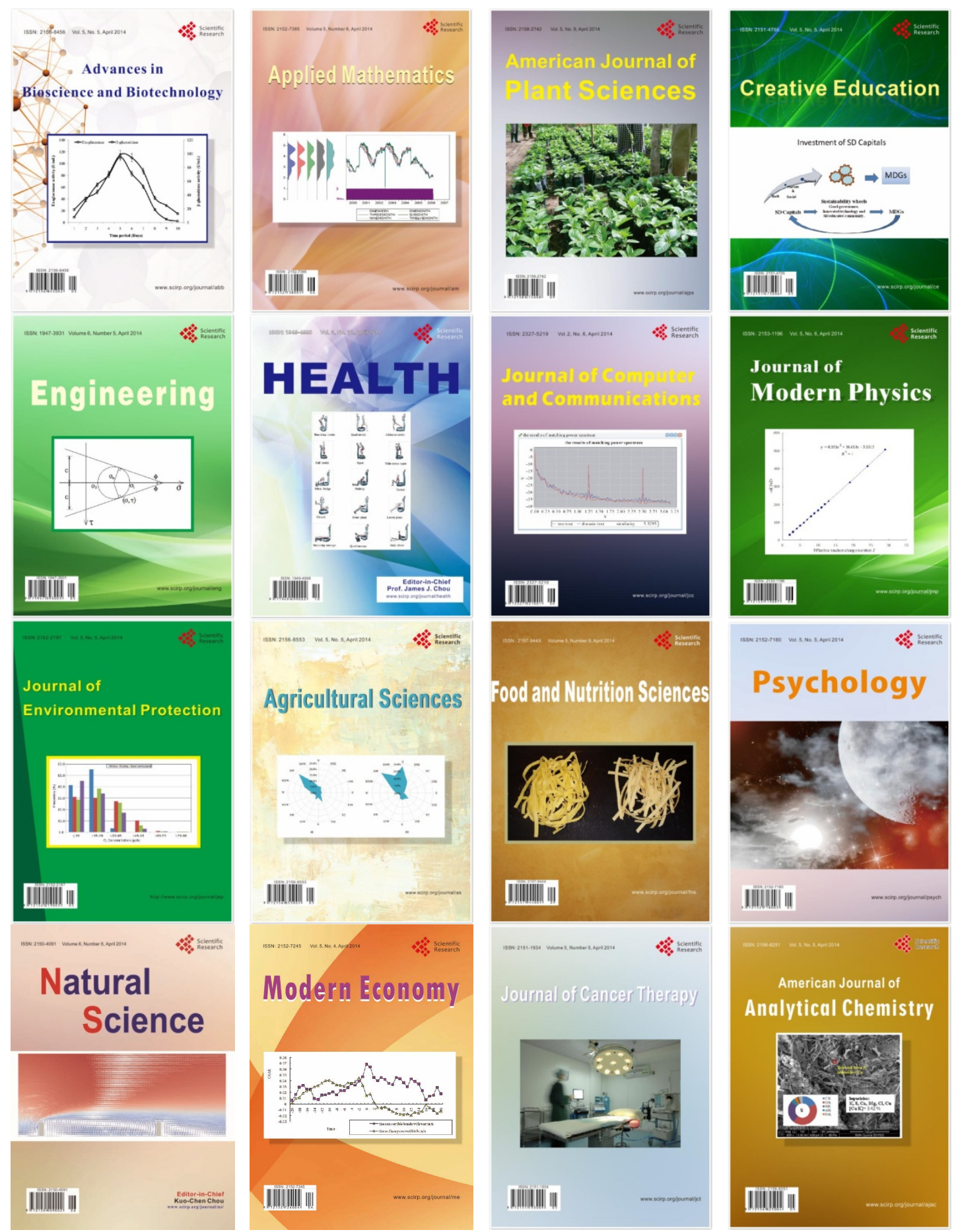